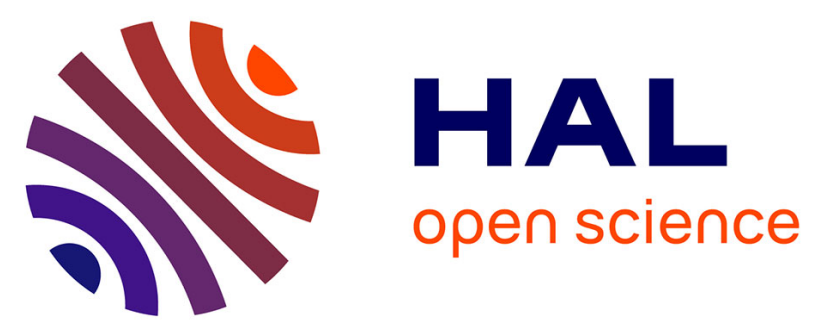

\title{
Detection of charged organic grains at the surface of Titan with the EFIELD/DraGMet sensor on board Dragonfly
}

\author{
Audrey Chatain, Alice Le Gall, Michel Hamelin, Jean-Jacques Berthelier, \\ Ralph D. Lorenz, Rafik Hassen-Khodja, Jean-Pierre Lebreton, Grégoire \\ Déprez
}

\section{To cite this version:}

Audrey Chatain, Alice Le Gall, Michel Hamelin, Jean-Jacques Berthelier, Ralph D. Lorenz, et al.. Detection of charged organic grains at the surface of Titan with the EFIELD/DraGMet sensor on board Dragonfly. vEGU21 - EGU General Assembly 2021, Apr 2021, Online, France. 10.5194/egusphereegu21-12900 . insu-03559301

\section{HAL Id: insu-03559301 https://hal-insu.archives-ouvertes.fr/insu-03559301}

Submitted on 7 Feb 2022

HAL is a multi-disciplinary open access archive for the deposit and dissemination of scientific research documents, whether they are published or not. The documents may come from teaching and research institutions in France or abroad, or from public or private research centers.
L'archive ouverte pluridisciplinaire HAL, est destinée au dépôt et à la diffusion de documents scientifiques de niveau recherche, publiés ou non, émanant des établissements d'enseignement et de recherche français ou étrangers, des laboratoires publics ou privés. 
EGU21-12900

https://doi.org/10.5194/egusphere-egu21-12900

EGU General Assembly 2021

(c) Author(s) 2022. This work is distributed under

the Creative Commons Attribution 4.0 License.

\title{
Detection of charged organic grains at the surface of Titan with the EFIELD/DraGMet sensor on board Dragonfly
}

\author{
Audrey Chatain ${ }^{1}$, Alice Le Gall ${ }^{1,2}$, Michel Hamelin' ${ }^{1}$, Jean-Jacques Berthelier ${ }^{1}$, Ralph D. Lorenz ${ }^{3}$, Rafik \\ Hassen-Khodja ${ }^{1}$, Jean-Pierre Lebreton ${ }^{4}$, and Grégoire Déprez ${ }^{5}$ \\ ${ }^{1}$ LATMOS, Université Paris-Saclay, UVSQ, Sorbonne Université, CNRS, Guyancourt, France (audrey.chatain@latmos.ipsl.fr) \\ ${ }^{2}$ Institut Universitaire de France (IUF), Paris, France \\ ${ }^{3}$ Johns Hopkins Applied Physics Laboratory, Laurel, MD, USA \\ ${ }^{4}$ LPC2E, CNRS, Université d'Orléans, Orléans, France \\ ${ }^{5}$ European Space Research and Technology Centre (ESTEC), Noordwijk, The Netherlands
}

Titan, the largest moon of Saturn, is the place in the Solar System showing the most Earth-like landscapes. Titan's dense atmosphere and cold temperatures enable a complex methane hydrological cycle that have shaped the surface, very similarly to the water cycle on Earth. Titan has another peculiar feature: a wealth of organic grains is created by photochemistry in its atmosphere and progressively deposited at its surface. Such atmospheric production of organics likely occurred on Earth before the apparition of life; that is the reason why a better understanding of the formation processes, chemical composition and physical properties of these grains is of great interest.

The Dragonfly mission has recently been selected by NASA to explore Titan's surface with a rotorcraft circa 2035 (Lorenz et al., 2018). Dragonfly will explore a region of organic sand dunes with monthly flights of a few kilometres each aiming to an impact crater named Selk. In addition to chemical analyses, Dragonfly is equipped with several sensors intended to characterize its environment. Among them, as part of the Dragonfly Geophysical and Meteorological (DraGMet) package, the EFIELD instrument will record the AC electric field at low frequencies $(\sim 5-100 \mathrm{~Hz})$.

EFIELD consists in two spherical electrodes accommodated at different locations on the rotorcraft. The main scientific objective of EFIELD is to measure Schumann Resonances on Titan. Such resonances may have been detected by the Huygens probe in 2005 (unless it was an artefact of probe motion; Lorenz and Le Gall, 2020) and would be an indication of the existence of an underground global salty ocean (Beghin et al., 2012). Another scientific objective of EFIELD is the detection and characterization of charged grains. This work is dedicated to this secondary objective.

The exploration area of Dragonfly is covered by sand grains, most likely organic in nature, maybe mixed with ice. Surface winds can sometimes put them in saltation or suspension. In the process, these organic grains are likely to get charged by friction (triboelectric effect; Méndez-Harper et al., 2017), and would then induce a perturbation on the electric field detectable by the EFIELD 
antennas. To estimate the significance of this perturbation and test the possibility to measure it, we have built a numerical model that simulates the trajectory of charged particles in the probe environment, subjected to turbulent wind flows, gravity and electrostatic forces. First results show that charged particles will induce a strong measurable signal on the EFIELD spectra. We are thus currently investigating how these spectra can be used to derive information on the grains (number, charge, size or density). On Titan, EFIELD will work in synergy with wind sensors and a microscopic imager that will observe grains deposited at the surface.

The next steps in our simulations will be to account for the perturbations induced by the nearby body of Dragonfly. In parallel, we are building a prototype antenna to test it and check the ability of our model to reproduce its measurements in the laboratory and in the frame of field campaigns. 